\title{
ALIGNMENT CHARTS FOR THE EFFECTIVE LENGTH FACTOR IN A FRAMED COLUMN INCLUDING SHEAR DEFORMATION
}

\author{
by MINORU MAKINO* and AKIO KAWANO** \\ Members of A.I.J.
}

\section{Introduction}

The elastic buckling load of a frame is an useful parameter for the prediction of the frame collapse load. In assessing the actual failure load the theoretical elastic buckling load of an overall frame is frequently obtained for the theoretical studies. However, it is scarecely obtained for the practical design of a frame, because that laborious computations are needed. This doesn't mean no need to consider the overall frame instability. It may be guaranteed by taking into account of the effective length of the each framed column for the practical design.

There are several proposals ${ }^{1>\sim^{4}}$ ) to estimate the approximate effective length of the framed column. So-called alignment charts, which are suggested in the CRC Guide ${ }^{5)}$ and are used as the basis for the AISC specifications, seem to be the simplest.

Recently, it is noticed ${ }^{(3), 7)}$ to estimate a frame stiffness more exactly in the dynamic analysis of multi-story steel frames. As often pointed out, the shear deformations of members in a frame affect the overall frame stiffness cosiderably. The effects of shear deformations of members, as a matter of course, make the frame stiffness reduce. The decrease of the frame stiffness corresponds to make effective lengths of each framed columns longer for the practical design.

In this paper, alignment charts for the effective length factor in a framed column including the shear deformation are proposed and illustrated a few examples to show the procedure to find the effective length factor and the effects of the shear deformations. Proposed alignment charts may be useful to consider the frame instability more precisely.

\section{§ 2. Buckling criteria of the column in a frame}

2-1 Basic assumptions

1) Columns in a frame are perfectly elastic and prismatic.

2) In the frame buckling the restraining moments from the beams at the joint may be balanced to the columns in proportion to their nominal stiffnesses.

3) Adjacent columns are assumed nearly identical in the shear-deformation parameter $\Phi$, which is expressed as $\Phi=\frac{12 E I}{G A_{s} l^{2}}$ where $E I$ and $G A_{s}$ are the flexural and shear rigidities and $l$ is the length of the member, respectively.

4) It may be assumed that a frame buckles totally when all columns of it buckle simultaneously and that the buckling criterion of the frame may be considered in a replaced subassemblage of a column and two beams connected at the both ends of

5) The effective length factor is expressed as

$$
K=\frac{l_{k}}{l}=\sqrt{\frac{P_{e}}{P_{c r}}}
$$

where $P_{e}=\frac{\pi^{2} E I}{l^{2}}$, the Euler load of the pin-ended column, and $P_{c r}$ is the buckling load of the subas-

* Professor, Department of Architecture, Faculty of Engineering, Kyusyu University, Dr. Eng.

** Research Assistant, Department of Architecture, Faculty of Engineering, Kyusyu University, Ma. Eng. 
semblage.

6) The nonlinear stiffness matrix of a beam element including the shear deformation may be given $^{8)}$ as

$$
[K]=\left[\begin{array}{cccc}
\alpha \frac{E I}{l} & \beta \frac{E I}{l} & r \frac{E I}{l^{2}} & -\gamma \frac{E I}{l^{2}} \\
& \alpha \frac{E I}{l} & r \frac{E I}{l^{2}} & -\gamma \frac{E I}{l^{2}} \\
\text { sym. } & & \delta \frac{E I}{l^{3}} & -\delta \frac{E I}{l^{3}} \\
& & & \delta \frac{E I}{l^{3}}
\end{array}\right]
$$

where the coefficients are

$$
\begin{aligned}
\alpha & =\frac{z(\sin z-a \cdot z \cdot \cos z)}{2-2 \cos z-a \cdot z \cdot \sin z}, \quad \beta=\frac{z(a \cdot z-\sin z)}{2-2 \cos z-a \cdot z \cdot \sin z} \\
r & =\frac{a \cdot z^{2}(1-\cos z)}{2-2 \cos z-a \cdot z \cdot \sin z}, \quad \delta=\frac{a^{2} \cdot z^{3} \cdot \sin z}{2-2 \cos z-a \cdot z \cdot \sin z}
\end{aligned}
$$

when a compressive axial force $P$ is presented, in which

$$
a=1-\frac{P}{G A_{s}}=1-\frac{\pi^{2}}{12} \Phi \frac{P}{P_{e}}, \quad z=\pi \sqrt{\left(\frac{P}{P_{e}}\right) \cdot \frac{1}{\left(1-\frac{\pi^{2}}{12} \Phi \frac{P}{P_{e}}\right)}}
$$

and

$$
\alpha=\frac{4+\Phi}{1+\Phi}, \quad \beta=\frac{2-\Phi}{1+\Phi}, \quad \gamma=\frac{6}{1+\Phi}, \quad \delta=\frac{12}{1+\Phi}
$$

when no axial force exists.

2-2 Criterion for an unbraced frame buckling (Sway columns)

Provided that the rotations at the far ends of restraining beams are equal in magnitude and same in sense to the joint rotations at the column end as shown in Fig. 1, which yield $\theta_{e}=\theta_{b}=\theta_{f}$ and $\theta_{c}=$ $\theta_{a}=\theta_{d}$. The modified slope-deflection equations for a subassemblage are, therefore, given as follows. Of course, the effects of the shear deformations in the beams are considered.

$$
\left.\begin{array}{l}
M_{a c}=\frac{E I_{b L L}}{l_{b L}} \cdot \frac{6}{1+\Phi_{b L L}} \cdot \theta_{a} \\
M_{a d}=\frac{E I_{b R L}}{l_{b R}} \cdot \frac{6}{1+\Phi_{b R L}} \cdot \theta_{a} \\
M_{b e}=\frac{E I_{b L U}}{l_{b L}} \cdot \frac{6}{1+\Phi_{b L U}} \cdot \theta_{b} \\
M_{b f}=\frac{E I_{b R U}}{l_{b R}} \cdot \frac{6}{1+\Phi_{b R U}} \cdot \theta_{b} \\
M_{a b}=\frac{E I_{c}}{l_{c}} \cdot\left\{\alpha \cdot \theta_{a}+\beta \cdot \theta_{b}-r \cdot\left(v_{b}-v_{a}\right) / l_{c}\right\} \\
M_{b a}=\frac{E I_{c}}{l_{c}} \cdot\left\{\beta \cdot \theta_{a}+\alpha \cdot \theta_{b}-\gamma \cdot\left(v_{b}-v_{a}\right) / l_{c}\right\}
\end{array}\right\}
$$

Using the assumptions, the equilibrium of the moments at the top and bottom joints of the column yields

$$
\left.\begin{array}{l}
M_{a b}+\frac{I_{c} / l_{c} \cdot\left(M_{a c}+M_{a d}\right)}{I_{c} / l_{c}+{ }_{A} I_{c} /{ }_{A} l_{c}}=0 \\
M_{b a}+\frac{I_{c} / l_{c} \cdot\left(M_{b e}+M_{b f}\right)}{I_{c} / l_{c}+{ }_{B} I_{c} /{ }_{B} l_{c}}=0
\end{array}\right\}
$$

Considering the equilibrium of the lateral forces in the column, since no lateral force

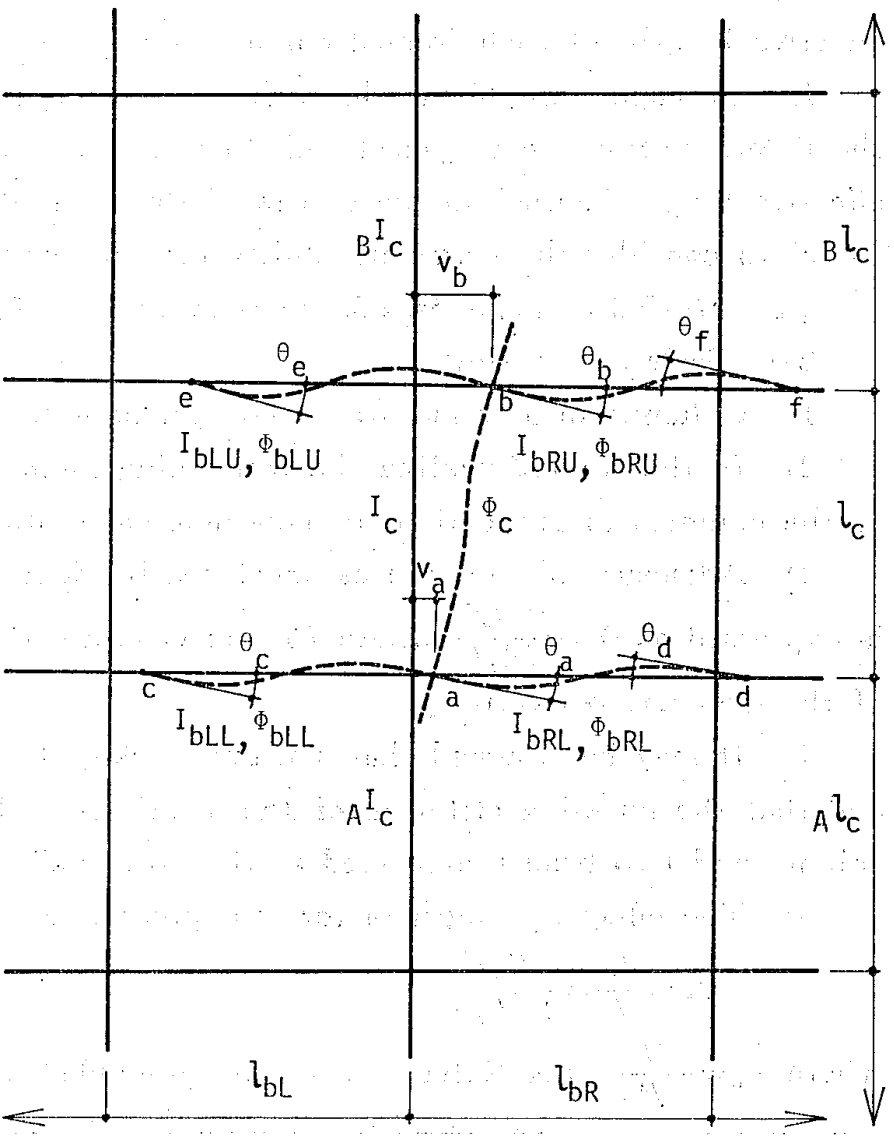

Fig. 1 Sway buckling mode 
exists, which yields,

$$
Q_{a b}+Q_{b a}=0
$$

or

$$
M_{a b}+M_{b a}+P \cdot\left(v_{b}-v_{a}\right)=0
$$

Substituting Eq. (2) into Eqs. (3) and (4), the buckling condition is found by setting the determinant of the coefficients of the unknown displacements equal to zero. Hence, the buckling condition for the sway column is given as

$$
\frac{z}{\tan z}=\frac{z^{2} \cdot G_{A} \cdot G_{B}-36}{6\left(G_{A}+G_{B}\right)}
$$

where

$$
G=\frac{\sum\left(I_{c} / l_{c}\right)}{\sum \frac{I_{b}}{l_{b}\left(1+\Phi_{b}\right)}}, \quad z=\pi \cdot \sqrt{\left(\frac{P}{P_{e}}\right) \cdot \frac{1}{\left(1-\frac{\pi^{2}}{12} \Phi_{c} \frac{P}{P_{e}}\right)}}
$$

This gives the same form with respect to the parameter $z$ as the buckling condition not including the shear deformations of the members. However, it should be noticed that the parameter $G$, which expresses the ratio of the sum of the column stiffnesses to the sum of the beam stiffnesses at the node meeting these members, contains the beam stiffness multiplied by a factor $\frac{1}{1+\Phi_{b}}$. Because the factor showing the effect of the beam shear deformation makes nominal beam stiffness reduce, the critical load decreases by relaxing of the end restraints from the beams.

2-3 Criterion for a braced frame buckling (No sway columns).

It may be assumed that $-\theta_{e}=\theta_{b}=-\theta_{f}$ and $-\theta_{c}=\theta_{a}=-\theta_{d}$ as shown in Fig. 2 for the no sway column case. Then, the modified slope-deflection equations are,

$$
\left.\begin{array}{rl}
M_{a c} & =\frac{2 E I_{b L L}}{l_{b L}} \cdot \theta_{a} \\
M_{a d} & =\frac{2 E I_{b R L}}{l_{b R}} \cdot \theta_{a} \\
M_{b e} & =\frac{2 E I_{b L U}}{l_{b L}} \cdot \theta_{b} \\
M_{b f} & =\frac{2 E I_{b R U}}{l_{b R}} \cdot \theta_{b} \\
M_{a b} & =\frac{E I_{c}}{l_{c}}\left(\alpha \cdot \theta_{a}+\beta \cdot \theta_{b}\right) \\
M_{b a} & =\frac{E I_{c}}{l_{c}}\left(\beta \cdot \theta_{a}+\alpha \cdot \theta_{b}\right)
\end{array}\right\}
$$

The joint equilibrium equations are the same that expressed in Eq. (3). Similarly, the buckling condition for the no sway column is given as

$$
\begin{array}{r}
\frac{G_{A} \cdot G_{B}}{4} \cdot a \cdot z^{2}+\frac{G_{A}+G_{B}}{2} \cdot\left(1-\frac{a \cdot z}{\tan z}\right) \\
+\left(\frac{\tan \frac{z}{2}}{\frac{z}{2}}-a\right)=0 \cdots(7)
\end{array}
$$

where

$$
\begin{aligned}
& G=\frac{\sum\left(I_{c} / l_{c}\right)}{\sum\left(I_{b} / l_{b}\right)} \\
& z=\pi \cdot \sqrt{\left(\frac{P}{P_{e}}\right) \frac{1}{\left(1-\frac{\pi^{2}}{12} \Phi_{c} \frac{P}{P_{e}}\right)}} \\
& a=1-\frac{\pi^{2}}{12} \Phi_{c} \frac{P}{P_{e}}
\end{aligned}
$$

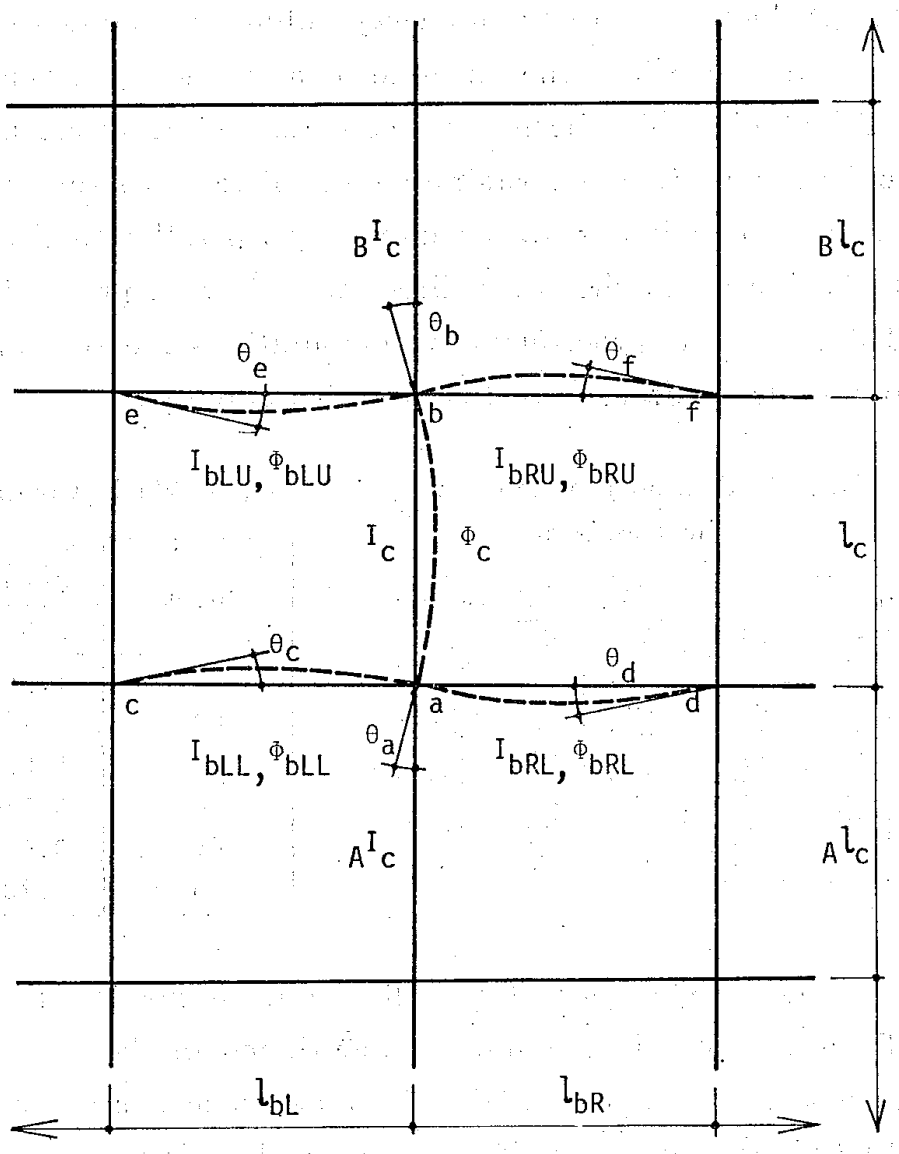

Fig. 2 No sway buckling mode 
The equation is slightly modified with a parameter, $a$, from the buckling condition not including the shear deformations of the members. However, the parameter $G$ is expressed a nominal stiffness ratio only because that the effects of the shear deformations in the beams are just cancelled through its derivation.

2-4 Correction factor into beam stiffness

Table 1 Correction factors of the beam when its far end condition is given

The factors by which the beam stiffness may be multiplied when the boundary conditions at the far end of the beam are definitely known are described in Table 1.

\section{\$3. Alignment charts}

The buckling conditions obtained from Eqs.

\begin{tabular}{|c|c|c|}
\hline $\begin{array}{c}\text { bucklingindary } \\
\text { mode cond. }\end{array}$ & hinged end & fixed end \\
\hline $\begin{array}{c}\text { Sidesway permitted } \\
\text { cond }\end{array}$ & $\frac{2\left(1+\Phi_{b}\right)}{4+\Phi_{b}}$ & $\frac{4+\Phi_{b}}{6}$ \\
\hline $\begin{array}{c}\text { Sidesway prevented } \\
1\end{array}$ & $\frac{6}{4+\Phi_{b}}$ & $\frac{4+\Phi_{b}}{2\left(1+\Phi_{b}\right)}$ \\
\hline
\end{tabular}

(5) and (7) may be conveniently expressed in well-known nomographic forms with the shear-deformation parameter $\Phi_{c}$ of the column. However, it may be very laborious to use so many nomographs prepared for each $\Phi_{c}$ even if possible. Consequently, condensed nomographic forms having the sheardeformation parameter $\Phi_{c}$ are proposed as shown in Fig. 3-a and 3-b for the unbraced frame buckling and the braced frame buckling, respectively.

Strictly speaking, as far as the braced frame buckling is concerned the ordinate of $G$-scale in the nomograph is slightly shifted between the terminals in accordance with parameter $\dot{D}_{c}$. However, in the nomograph shown in Fig. 3-b $G$-values are plotted for the case of $\Phi_{c}=0$. Consequently $K$-values are modified for the column restrained equally in both ends. In the case of the greatest $\Phi_{c}$ in Fig. 3 -b the error is estimated only about $2 \%$ at the most for a column with a hinged and fixed boundary at the both ends.

\section{\$4. Numerical examples}

At first, the procedure to find the effective length factor on the proposed alignment chart is illustrated in Fig. 4. Given $G_{A}$ and $G_{B}$ are 1.5 and 0.5 respectively and $\Phi_{c}$ is 0.25 , the effective length factor $K$ for a no sway column is found to be 0.88 .

Next, consider the example of a two story frame shown in Fig. 5, which is illustrated in the CRC Guide. The beams and columns in the frame have various boundary conditions as a illustration and columns in the upstairs are permitted to sway and columns in the downstairs are prevented to sway. All columns are oriented webs parallel to the plane of the drawing. All columns are assumed to be braced in the weak direction. Section properties of the members in the frame are shown in Table 2. The procedures of computations are the same as the illustration of the CRC Guide and its proposals to design practice are also adopted.

Table 2 Section properties of the members

\begin{tabular}{|c|c|c|c|c|}
\hline Hember & Designation & $\begin{array}{l}\text { Moment of } \\
\text { Inertia } \\
\text { I (in. }\end{array}$ & $\begin{array}{c}\text { Shear } \\
\text { Areas? } \\
\text { Agsin? }\end{array}$ & \begin{tabular}{|l|} 
Shear \\
Paranieter \\
$\Phi$
\end{tabular} \\
\hline 81 & 12427 & 204.1 & 2.65 & 0.085 \\
\hline B 2 & $12 \mathrm{~W} 27$ & 204.1 & 2.65 & 0.069 \\
\hline вз & $14 \mathrm{~W}=30$ & 289.6 & 3.54. & 0.196 \\
\hline 84 & $146 F 30$ & 289.6 & 3.54 & 0.090 \\
\hline 85 & $146 \mathrm{~F} 30$ & 289.6 & 3.54 & 0.074 \\
\hline $\mathrm{Cl}$ & 6WF 15.5 & 30.3 & 1.29 & 0.042 \\
\hline $\mathrm{C} 2$ & $86 \sqrt{31}$ & 109.7 & 2.05 & $0.096^{\circ}$ \\
\hline C3. & $6 \mathrm{~W} 15.5$ & 30.3 & 1.29 & 0.070 \\
\hline$c 4$ & $6 W=15.5$ & 30.3 & 1.29 & 0.038 \\
\hline c5 & $64 F 15.5$ & 30.3 & 1.29 & 0.038 \\
\hline c6 & $8 \mathrm{WF} 31$ & 109.7 & 2.05 & 0.087 \\
\hline
\end{tabular}

Table 3 Comparison of the effect due to the shear deformation

\begin{tabular}{|c|c|c|c|c|c|}
\hline \multirow{2}{*}{ Column } & \multicolumn{2}{|c|}{$\begin{array}{l}\text { Neglected shear } \\
\text { deformation }\end{array}$} & \multicolumn{2}{|c|}{$\begin{array}{l}\text { Considered shear } \\
\text { deformation }\end{array}$} & \multirow{2}{*}{$\begin{array}{c}\text { Rate of } \\
\text { Increase } \\
\qquad(\%)\end{array}$} \\
\hline & $K$ & 1 & K & $l$ & \\
\hline $\mathrm{Cl}$. & 1.06 & $11^{\prime}-8 "$ & 1.07 & $11^{\prime}-10^{\prime \prime}$ & 1.0 \\
\hline $\mathrm{C} 2$ & 1.18 & $13^{\prime}-0^{\prime \prime}$ & 1.22 & $13^{\prime}-5^{\prime \prime}$ & 3.4 \\
\hline C. 3 & 1.89 & $\left.16^{\prime}-\right]^{\prime \prime}$ & 1.90 & $16^{\prime}-2^{\prime \prime}$ & 0.5 \\
\hline C4 & 0.86 & $9^{\prime}-17 "$ & 0.88 & $10^{\prime}-2^{\prime \prime}$ & 2.3 \\
\hline C5 & 0.65 & $7^{\prime}-6^{\prime \prime}$ & 0.67 & $7 !-9 "$ & 3.1 \\
\hline C6 & 0.78 & $9^{\prime}-0^{\prime \prime}$ & 0.82 & $9^{\prime}-5^{\prime \prime}$ & 5.1 \\
\hline
\end{tabular}

The comparisons of the effect due to the shear deformation in the members are summarized in Table 3. In this example, as mentioned in the CRC Guide, it is not intended to illustrate a certain actual structure so that the shear deformations are not so remarkable. However, the column of $\Phi_{c}=$ 0.087 increased about $5 \%$ in the buckling length.

\section{$\S 5$. Conclusion}




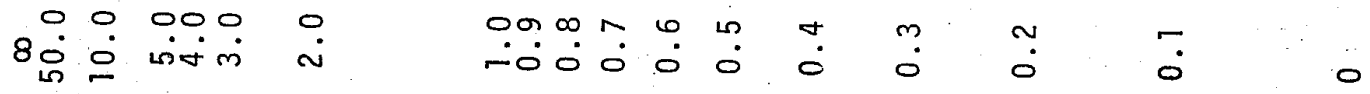

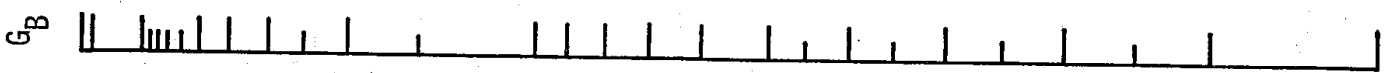

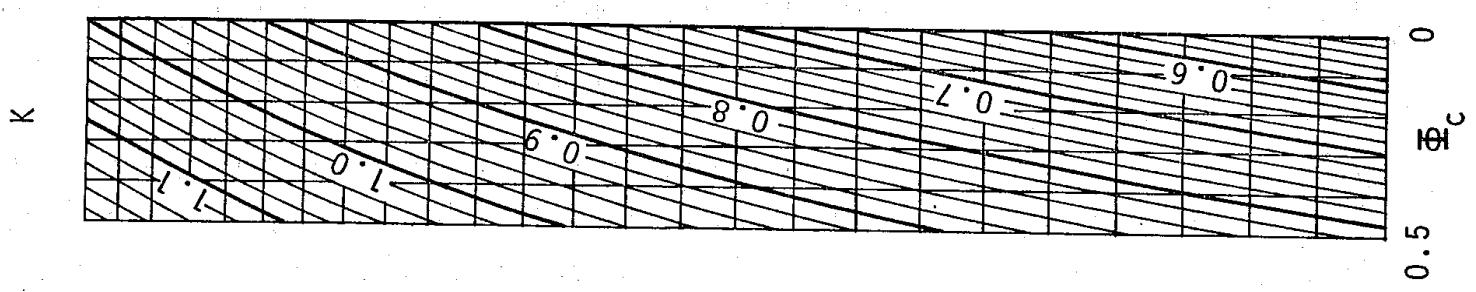

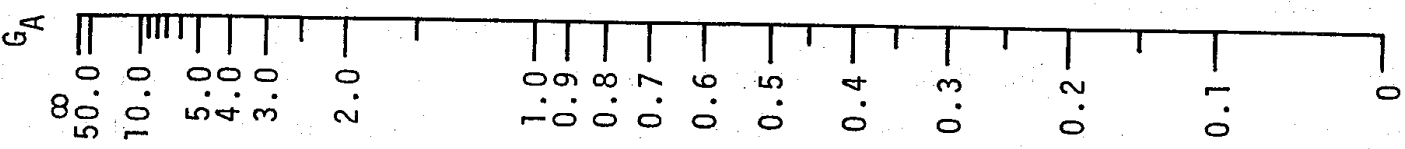

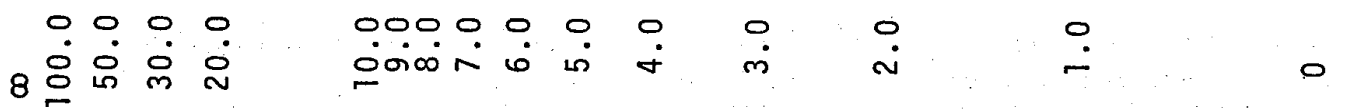

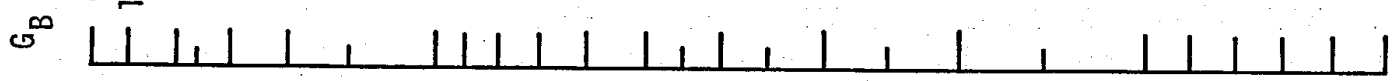
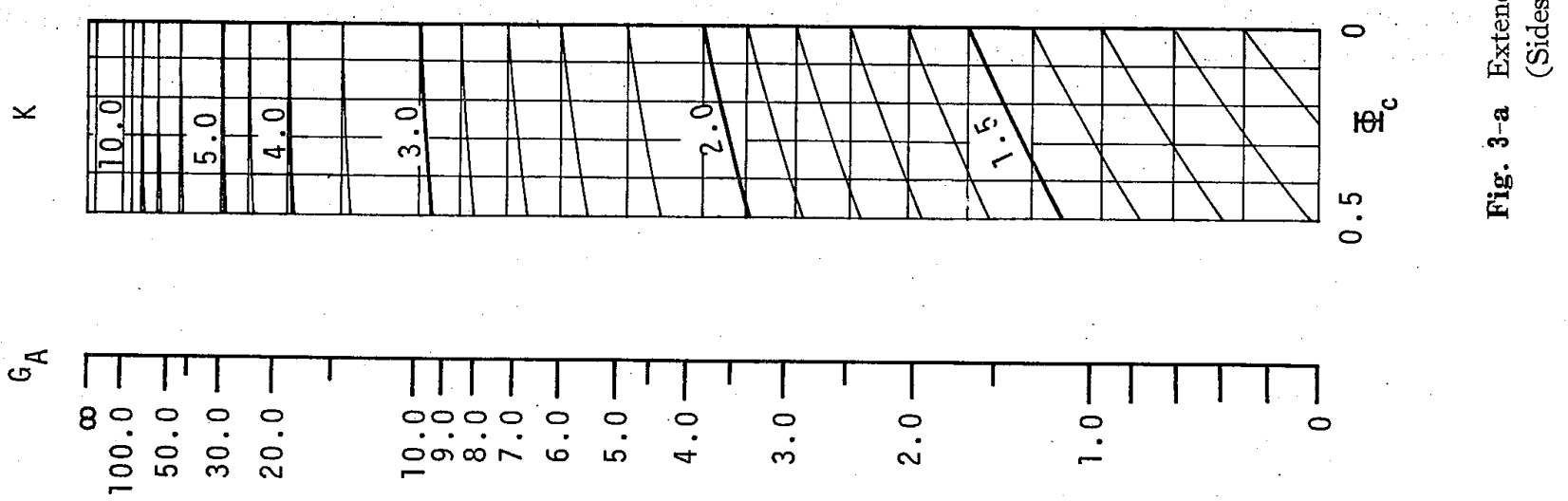


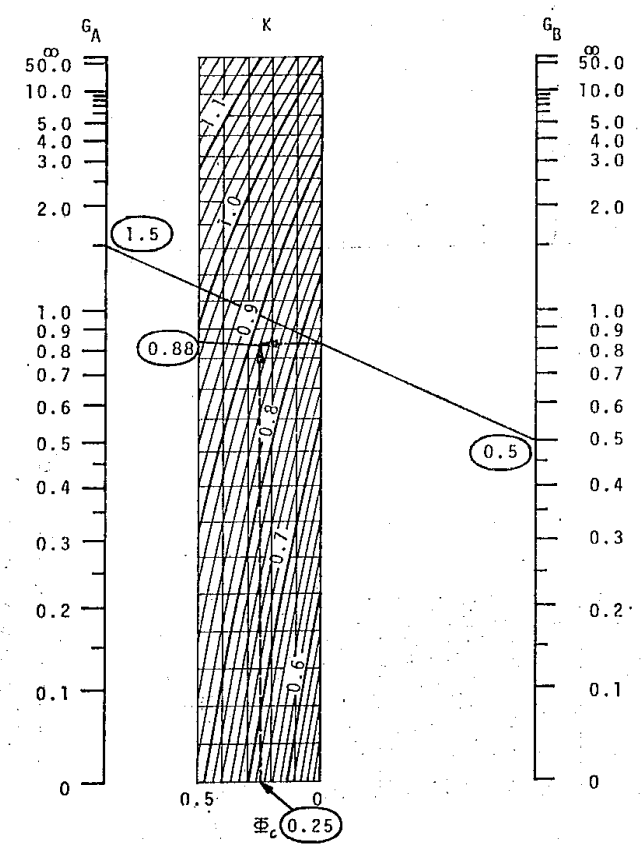

Fig. 4 Procedure for the effective length factor (Sidesway prevented)

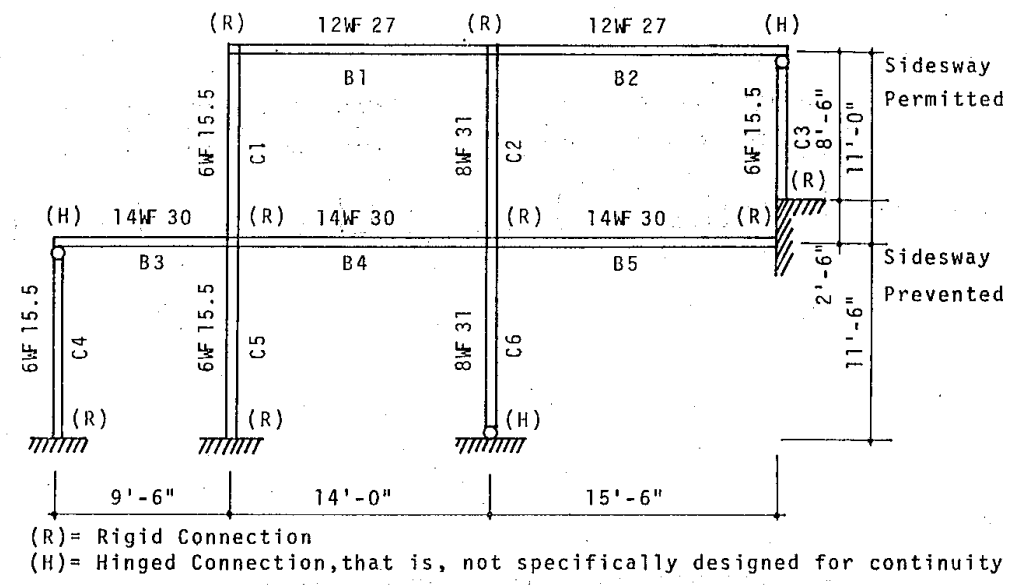

Fig. 5 Model frame in the CRC Guide

It is easy to obtain the effective length of: a framed column including the shear deformation by using the proposed extended nomographs herein.

At first sight the effect due to the shear deformation is apparent in these nomographs as a function of the

shear-deformation parameter $\Phi_{c}$. The effect seems to be much more sensitive for the no sway buckling mode than for the sway mode. The proposed extended alignment charts may be useful to consider the frame instability more precisely.

\section{Acknowledgements}

The writers are grateful to Mr. O. Anegawa and Mr. Y. Matsuda, who were undergraduate students in Kyusyu University, for their contributions to establish the nomographs in their thesis.

\section{References}

1) Bleich H.H., "Buckling Strength of Metal Structures", McGraw-Hill Book Co., Inc., 1952.

2) Hoff N.J., "The Analysis of Structures", John Wiley \& Sons, Inc., 1956.

3) Pflüger A., "Stabilitätsprobleme der Elastostatik", Springer Verlag, 1964.

4) Wood R.H., "Effective Lengths of Columns in Multi-storey Buildings", Part 1, The Structural Enginerr, No. 7 Vol. 52, July 1974.

5) Johnston B.G., "The Guide to Design Criteria for Metal Compression Members", 2nd. ed.; John Wiley \& Sons, Inc., 1966.

6) Muto K. and et al., "Earthquake Response Analysis of C-Building (25-story frame) Considered of the Axial Displacement of Members, the Shear Deformation of Members and of Beam-Column Connections", Trans. of A.I.J., Extra Summaries of Technical Papers of Annual Meeting of A.I.J., 1968.

7) Muto Institute of Structural Mechanics, "Method of Frame Analysis in Consideration of Pure-Shear Panel Deformation (No. 2)", Leaflet No. 101, FAPP-Method.

8) Makino M. and Kawano A., "On the Nonlinear Stiffness Matrix for a Beam Element Including of Shear Deflection", Transactions of A.I.J., No. 245, July 1976. 


\section{せん断変形を考慮した有効座屈長さ係数図表（梗概）}

$\begin{array}{cccc}\text { 正会員 } & \text { 牧 野 } & \text { 稔* } \\ \text { 同 } & \text { 河 } & \text { 野 昭 } & \text { 雄** }\end{array}$

骨組の弾性座屈荷重は骨組の実際の崩壊荷重を予測す る重要なパラメーターの1つである。しかし，実施設計 の段階においては骨組の弾性座屈荷重を求めることは殆 んぞない。これは骨組の安定性を考光ないといらことで はなく，骨組の中の柱材の有効座屈長さを考えることに より，全体骨組の安定性が一応保証されるためである。

最近, 高層骨組の振動解析以際し, 骨組の岡性を正確 に評価しようとすることから，部材のせん断変形を考慮 することが行なわれていて，その影響がかなり大きいこ とがわかっている。したがって, 部材のせん断変形の影 響で骨組の弾性座屈猗重も低下寸るであるらことは予想 される。本論文では，全体骨組座屈を骨組を構成する部 分構造の座屈問題に置換し, 部材にせん断変形を考慮す る場合の, 部分構造の中の柱材の有效座届長さ係数を求 める nomograph を提案する。これはアラインメントチ ヤートと呼ばれているものに, 部材のせん断変形の効果 を表わすパラメーター $\Phi\left(=\frac{12 E I}{G A_{s} \cdot l^{2}}\right)$ を導大し, 拡張 したものである。

上述のように，本諭文では全体骨組を1本の柱と，そ の上下端でそれぞれ 2 本の剛接されたはりから構成する 部分構造に置換し，その座屈を考えるが，水平移動形， 水平移動拘束形の座屈モードに対し, それぞれの座届条 件式を誘導する。柱材の節点力と節点変位の関係は, 先 に, 筆者が提案したせん断変形を考慮する座屈挩角法基 本式を使う。座屈条件式を誘導する際に，はりのせん断 変形も当然考慮している。

まず, 水平移動形座屈条件式はせん断変形を考慮しな

* 九州大学教授 - 工博

** 九州大学助手・工修

(昭和 51 年 5 月 26 日本稿受理・討論期限昭和 52 年 1 月 1 日)
い場合とその形が同じであるが，柱一はり剛度の比 $G$ を 計算する際，はりのせん断変形による効果を含めねばな らない。一方, 水平移動拘束形座屈条件式の場合は, 世 ん断変形を考慮しない条件式にパラメーター $a$ 注(1) が若 干附加された形となるが，はりのせん断変形効果は $G$ の計算式には表われてこない。これらの座屈条件式をも とに，オイラー荷重に対する有効座屈長さ係数を求める nomograph を作成した。せん断変形パラメーターФの それぞれの值に対して，厳密には，グラフをそれぞれ求 めるべきであるが，簡便の為，1つのグラフにをとめた。 その結果, 特に水平移動拘束形のグラフでは, 実際は Ф のそれぞれの值に対して $G$ 目盛が異なってくるが，提 案したグラフでは $\Phi=0$ に対してのみ $G$ の值を目盛り, それに対応する有効座届長さ係数 $K$ の值は, 柱の上下 の $G$ の值が等しい場合の值をプロットした。このため, $G$ 值の，柱の上下における差が大きくなるにつれて $K$ 值獃差を生ずることになるが，それでも高々 $2 \%$ で 実用上差し支えない範囲である。計算例として，CRC Guide注(2) の骨”組モデルを使い，せん断変形を考慮する 場合と考慮しない場合の, 有效座屈長さ係数を比較計算 した。この骨組程度の比較的軽微な柱材でも約 $5 \%$ の影 響量がでている。

ここで提案する, 部材のせん断变形を考慮する有効座 届長さ係数を求める拡張された nomograph は, 骨組の 安定性を, より正確に評価する場合に有効であるう。

注 (1) $a=1-\frac{P}{G A_{s}}, P$ は柱の圧縮軸力, $G A_{s}$ はせん断剛 性.

注 (2) Johnston B.G., "The Guide to Design Criteria for Metal Compression Members"', 2nd ed., John Wiley \& Sons, Inc., 1966. 